\title{
An analysis of the characteristics of Chinese listed companies' independent director system
}

(C) Higher Education Press and Springer-Verlag 2007

\begin{abstract}
From three different perspectives, namely, the basic characteristics of independent directors, the percentage of independent directors on board and its relation to company performance, and the remuneration for independent directors and its relation to company performance, we could summarize implementation characteristics of the independent director institution in China: the age distribution of independent directors is relatively even and the majority of them are academic staff and researchers with business administration backgrounds; a positive relationship between the independent director's remuneration and company performance, as well as between the number of independent directors on board and the company performance.
\end{abstract}

Keywords listed companies, independent directors, characteristics of independent directors, remuneration for independent directors, company performance

摘要 从独立董事的基本特征、独立董事占董事会比例及其与公司绩效的关 系、独立董事薪酬特点及其与公司绩效的关系等方面对该制度的实施情况进行分 析, 可总结出我国上市公司独立董事制度的实施特征，即独立董事年龄分布均 匀, 大多数有经济管理研究背景, 独立董事的薪酬同公司绩效联系紧密, 独立董 事数量同该公司效益成正相关。

关键词上市公司, 独立董事, 独立董事特征, 独立董事薪酬, 公司业绩

Translated from Guanli Shijie 管理世界 (Management World), 2003, (6): 110-121

TAN Jinsong $(\bowtie)$, LI Minyi, LI Wenjing, ZHENG Heng, WU Jianlin, LIANG Yu School of Business, Sun Yat-sen University, Guangzhou 510275, China

E-mail: china_tjs@263.net 


\section{Introduction}

In 1993, "Tsingtao Brewery" became the first listed mainland company at Hong Kong Exchange. It was also the first mainland company to introduce independent directors to its board of directors. Since then, an increasing number of Chinese listed companies have implemented the independent director institution. In many government regulations that followed, the institution was repeatedly mentioned (for details, please refer to the Guidelines for the Charter of Listed Companies issued by China Securities Regulatory Committee (CSRC) in Dec, 1997, and Suggestions for Further Standardizing Operations and Intensifying Reform of Companies Listed Outside China co-issued by the State Economic and Trade Commission (SETC) and CSRC on March 29, 1999). In August, 2001, CSRC issued the Guidelines for Introducing Independent Directors to the Board of Directors of Listed Companies (hereinafter as "the Guidelines"), symbolizing a full-scale implementation of the independent director institution in Chinese listed companies. Five months later, SETC and CSRC re-emphasized the establishment of the institution in the Code of Corporate Governance for Listed Companies in China. It is foreseeable that the independent director institution will be a hot topic in China's corporate governance and thus of great study significance.

The purpose of this study was to understand the implementation of independent director institution in China, to evaluate and analyze its implementation systematically, and find out its characteristics and general trends so as to provide empirical evidences and support for enhancing the independent director institution and corporate governance in China. We collected from secondary sources relevant data $^{1}$ of 2,207 independent directors (occupying 2689 independent director positions) among 1186 Chinese listed companies (data up to August 31, 2002) as the population. Among these companies, 1047 of them issued A shares only and 139 companies issued $\mathrm{B}$ shares or $\mathrm{H}$ shares. Considering the requirements for corporate governance in different market environments are different, we categorized the population into three subsamples: (1) A-share only companies; (2) B-share or H-share companies, including companies which issue both $\mathrm{A}$ shares and $\mathrm{B} / \mathrm{H}$ shares, and companies which only issue $\mathrm{B}$ shares or $\mathrm{H}$ shares; (3) the combination of subsample (1) and $(2)^{2}$.

The structure of this paper is as follows: Section 2 presents a preliminary analysis of the independent directors' demographic characteristics; Section 3 analyzes the relationship between the number/percentage of independent directors

\footnotetext{
${ }^{1}$ Statistics obtained from www.p5w.net, www.genius.com.cn, www.cninfo.com.cn, and China Securities Journal, Shanghai Securities Journal.

${ }^{2}$ The purpose of using three subsamples is to test the variances between A Share and $\mathrm{B}(\mathrm{H})$ Share companies in terms of the implementation of the independent director institution.
} 
on board and company performance; Section 4 discusses the remuneration for independent directors in Chinese listed companies and its relationship with company performance.

\section{Profiles of independent directors of Chinese listed companies}

\subsection{Demographic characteristics of independent directors}

The demographic characteristics of Chinese independent directors mainly include items such as career background, academic background, professional specialization, knowledge structure and age. They mainly deal with the question "Who qualifies as an independent director in China."

Generally speaking, the specific function and purpose of the board of directors determine its structure. Different kinds of boards need different directors, just like the implementation of the independent director institution is to enforce the board's supervision and control over management and reduce the insider control problem. On the other hand, the board structure also decides its working style and whether its goal would be achieved.

From the company and the board's stances, both independent directors and non-independent directors are board members in nature. The individual characteristics of independent directors should be in consistent with the board's missions and help maintain the board's overall image. Thus we need to pay attention to the optimal matching of directors (among independent directors; with other directors; between independent and other directors) including age, professional specialization, experience, personality and academic background, so that the board's missions can be better fulfilled. Also, some of the company's special needs should also be considered. For example, companies with weak financial management may appoint several directors (including independent ones) with financial accounting background; those need to enhance connection with relevant government departments may need more independent directors with governmental service experience; the board with a majority of directors trained in social science schools may prefer to hire independent directors with science and technology background. In addition, the role of an independent director to be played determines the candidate's individual characteristics. Three typical roles of independent directors are discussed commonly: (1) supervision, (2) strategic role, and (3) governmental relations (Luo, 2001). Statistics show that when a company is under financial crisis, it tends to appoint bankers or other outside shareholders as their independent directors; while under government supervision, it prefers to select those with government service experience or legal background as independent directors (Luo, 2001). 
Kong (2001, 2002) described an ideal independent director candidate as follows: ages 35 to 55, has a deep understanding of the importance of cash flow and earnings per share. He is probably a successful manager of another non-interlocked company. He has the courage to speak without reservation and stand out to disagree with the chairman or CEO. He is able to explicitly and clearly express his opinions and is qualified enough to take up the post of board chairman when necessary. Most researchers agree that independent directors can play active roles in supervising the company's daily operation, enhancing company performance and protecting shareholders' interests. According to the above standards, a majority of independent director's posts should be held by researchers or practitioners from the fields of business management, financial accounting, law, and investment analysis.

Brickly et al. (1994) divided independent directors into four categories by their careers: (1) managers from other business entities which have little connection with the company, (2) private investors, (3) educative personages, government officials and priests, (4) so called professional directors. In a similar vein, Rosenstein and Wyatt (1990) categorized independent directors into financial type, corporate type and neutral type. The financial type refers to those employed by banks or other non-bank financial entities. The corporate type independent directors work in other companies. The neutral type independent directors are people who do not belong to either of the above types, including lawyers, professors and retirees. Rosenstein and Wyatt found no clear evidence that independent directors of any particular type are more or less valuable than others (Shen, 2001).

Tables 1-6 exhibit the demographic characteristics ${ }^{3}$ of Chinese independent directors.

Table 1 Age distribution of independent directors

\begin{tabular}{|c|c|c|c|c|c|c|}
\hline \multirow[t]{2}{*}{ Age } & \multicolumn{2}{|c|}{ A share only } & \multicolumn{2}{|c|}{$\mathrm{B}(\mathrm{H})$ share } & \multicolumn{2}{|c|}{ Total } \\
\hline & Number & Percent & Number & Percent & Number & Percent \\
\hline Under 40 & 540 & 27.34 & 44 & 18.97 & 584 & 26.46 \\
\hline $40-50$ & 601 & 30.43 & 79 & 34.52 & 680 & 30.81 \\
\hline $50-60$ & 351 & 17.77 & 45 & 19.40 & 396 & 17.94 \\
\hline Above 60 & 410 & 20.76 & 53 & 22.84 & 463 & 20.98 \\
\hline N/A & 73 & 3.70 & 11 & 4.75 & 84 & 3.81 \\
\hline Total & 1975 & 100.00 & 232 & 100.00 & 2207 & 100.00 \\
\hline
\end{tabular}

\footnotetext{
${ }^{3}$ With regard to the individual independent director measurement, if one serves in two or more companies concurrently, he is counted for one only.
} 
Table 2 Occupation distribution of independent directors

\begin{tabular}{|c|c|c|c|c|c|c|}
\hline \multirow[t]{2}{*}{ Occupation } & \multicolumn{2}{|c|}{ A share only } & \multicolumn{2}{|c|}{$\mathrm{B}(\mathrm{H})$ share } & \multicolumn{2}{|c|}{ Total } \\
\hline & Number & Percent & Number & Percent & Number & Percent \\
\hline $\begin{array}{l}\text { University } \\
\text { teachers and } \\
\text { researchers }\end{array}$ & 811 & 41.06 & 62 & 26.72 & 873 & 39.56 \\
\hline Solicitors & 129 & 6.53 & 23 & 9.91 & 152 & 6.89 \\
\hline Accountants & 171 & 8.66 & 18 & 7.76 & 189 & 8.56 \\
\hline Industrialists & 244 & 12.35 & 61 & 26.29 & 305 & 13.82 \\
\hline Retirees & 173 & 8.76 & 22 & 9.48 & 195 & 8.84 \\
\hline Consultants & 168 & 8.51 & 8 & 3.45 & 176 & 7.97 \\
\hline Others & 209 & 10.58 & 17 & 7.33 & 226 & 10.24 \\
\hline N/A & 70 & 3.54 & 21 & 9.05 & 91 & 4.12 \\
\hline Total & 1975 & 100.00 & 232 & 100.00 & 2207 & 100.00 \\
\hline
\end{tabular}

Note: Industrialists refer to senior executives at other companies.

Table 3 Professional title distribution of independent directors

\begin{tabular}{|c|c|c|c|c|c|c|}
\hline \multirow[t]{2}{*}{ Class } & \multicolumn{2}{|c|}{ A share only } & \multicolumn{2}{|c|}{$B(H)$ share } & \multicolumn{2}{|c|}{ Total } \\
\hline & Number & Percent & Number & Percent & Number & Percent \\
\hline Senior & 1155 & 58.48 & 170 & 73.28 & 1325 & 60.04 \\
\hline Intermediate & 140 & 7.09 & 36 & 15.52 & 176 & 7.97 \\
\hline Other & 2 & 0.10 & 0 & 0.00 & 2 & 0.09 \\
\hline N/A & 678 & 34.33 & 26 & 11.21 & 704 & 31.90 \\
\hline Total & 1975 & 100.00 & 232 & 100.00 & 2207 & 100.00 \\
\hline
\end{tabular}

Table 4 Professional specialization distribution of independent directors

\begin{tabular}{|c|c|c|c|c|c|c|}
\hline \multirow{2}{*}{$\begin{array}{l}\text { Professional } \\
\text { specialization }\end{array}$} & \multicolumn{2}{|c|}{ A share only } & \multicolumn{2}{|c|}{$\mathrm{B}(\mathrm{H})$ share } & \multicolumn{2}{|c|}{ Total } \\
\hline & Number & Percent & Number & Percent & Number & Percent \\
\hline Accounting & 197 & 9.97 & 12 & 5.17 & 209 & 9.47 \\
\hline Law & 164 & 8.30 & 28 & 12.07 & 192 & 8.70 \\
\hline Business administration & 489 & 24.76 & 58 & 25.00 & 547 & 24.78 \\
\hline technology & 136 & 6.89 & 30 & 12.93 & 166 & 7.52 \\
\hline Other & 99 & 5.01 & 5 & 2.16 & 104 & 4.71 \\
\hline N/A & 890 & 45.06 & 99 & 42.67 & 989 & 44.81 \\
\hline Total & 1975 & 100.00 & 232 & 100.00 & 2207 & 100.00 \\
\hline
\end{tabular}

Note: Technology indicates the independent director's professional specialization is in line with the listed company's industry. 
Table 5 Academic degree distribution of independent directors

\begin{tabular}{|c|c|c|c|c|c|c|}
\hline \multirow[t]{2}{*}{ Academic degree } & \multicolumn{2}{|c|}{ A share only } & \multicolumn{2}{|c|}{$\mathrm{B}(\mathrm{H})$ share } & \multicolumn{2}{|c|}{ Total } \\
\hline & Number & Percent & Number & Percent & Number & Percent \\
\hline $\mathrm{PhD}$ & 443 & 22.43 & 46 & 19.83 & 489 & 22.16 \\
\hline Master & 488 & 24.71 & 54 & 23.28 & 542 & 24.56 \\
\hline Bachelor & 570 & 28.86 & 77 & 33.19 & 647 & 29.32 \\
\hline Other & 108 & 5.47 & 15 & 6.47 & 123 & 5.57 \\
\hline N/A & 366 & 18.53 & 40 & 17.24 & 406 & 18.40 \\
\hline Total & 1975 & 100.00 & 232 & 100.00 & 2207 & 100.00 \\
\hline
\end{tabular}

Taken together, Chinese independent directors' demographic characteristics are as follows:

1) As shown in Table 1, the age distribution of each age group is relatively even, with a range of $20 \%$ to $30 \%$, in the sub-samples and the population. Independent directors aged 40-50 occupy a highest percentage of over $30 \%$ in all sub-samples. More than half of them are under 50.

2) The majority of the independent directors are university teachers and researchers (about 40\%), next highest with industrialists, with a percentage of over $10 \%$ in all three samples. The percentages of the professionals such as accountants, lawyers and consultants are approximately the same, ranging from 5\% to $8 \%$. More supports can be found in Table 6, which ranks the top 10 organizations with the highest number of independent directors. Most of these organizations are prestigious universities in China. Statistics also shows that universities still dominate an absolute majority of the list of top 20 organizations with the highest number of independent directors, indicating that university teachers consist of the main body of independent directors in China. In contrast, most independent directors in developed countries are in-service or retired entrepreneurs, certificated public accountants and experienced lawyers, with only a small fraction of scholars ${ }^{4}$.

3) Most of (approximately $60 \%$ in all three samples) the independent directors in China hold senior professional titles. Only less than $10 \%$ hold intermediate professional titles or below. By deducting the influence of missing data, the percentage of senior professional title should arrive at around 90\%. As to the distribution of academic degrees, about half of the independent directors hold masters or doctoral degrees. The percentage could be even higher if the influence of missing data were deducted. In short, most Chinese independent directors hold both senior professional titles and high academic degrees, indicating that they are undoubtedly experts in their own sections.

\footnotetext{
${ }^{4}$ The high percentage of independent director positions being held by academics may have something to do with the perception that they may feel less insecure toward the uncertainty associated with the position (AI, 2002).
} 
Table 6 Top 10 Institutions with the largest number of independent directors

\begin{tabular}{llc}
\hline \multicolumn{2}{c}{ A share only } \\
\hline Rank & \multicolumn{1}{c}{ Institution } & $\begin{array}{c}\text { Number of listed } \\
\text { companies served }\end{array}$ \\
\hline 1 & Tsinghua University & 39 \\
2 & Shanghai University of Finance and Economics & 37 \\
3 & Renmin University & 36 \\
4 & Xiamen University & 32 \\
5 & Peking University & 27 \\
6 & Wuhan University & 27 \\
7 & Nanjing University & 23 \\
8 & Nankai University & 23 \\
9 & Fudan University & 20 \\
10 & Southwestern University of Finance & 19 \\
\hline
\end{tabular}

\begin{tabular}{ll}
\hline Rank Institution & $\begin{array}{l}\text { Number of listed } \\
\text { companies served }\end{array}$
\end{tabular}

\begin{tabular}{llc}
\hline 1 & Shanghai University of Finance and Economics & 12 \\
2 & Fudan University & 7 \\
3 & TsingHua University & 7 \\
4 & Shanghai Jiaotong University & 5 \\
5 & East China University of Politics and Law & 4 \\
6 & Industrial and Commercial Bank of China & 4 \\
7 & Wuhan University & 4 \\
8 & Peking University & 3 \\
9 & Shanghai State Asset Management Limited company & 3 \\
10 & Tongji University & 3 \\
\hline
\end{tabular}

Total sample

\begin{tabular}{ll}
\hline Rank Institution & $\begin{array}{l}\text { Number of listed } \\
\text { companies served }\end{array}$ \\
\hline
\end{tabular}

\begin{tabular}{lll}
\hline 1 & Shanghai University of Finance and Economics & 49 \\
2 & TsingHua University & 46 \\
3 & Renmin University & 36 \\
4 & Xiamen University & 32 \\
5 & Wuhan University & 31 \\
6 & Peking University & 30 \\
7 & Fudan University & 27 \\
8 & Nanjing University & 25 \\
9 & Nankai University & 23 \\
10 & Shanghai Jiaotong University & 20 \\
\hline
\end{tabular}


4) The distribution of professional specialization is shown in Table 4. Directors with economic management background take up a highest percentage of around $25 \%$ in all three samples ${ }^{5}$. Approximately $10 \%$ independent directors are specialized in accounting and law and 7\% in "technology". 6

Several phenomena are worth noticing:

1) The percentage of industrialists holding posts as independent directors is $12.35 \%$ in A share companies and $22.04 \%$ in B (H) share companies respectively. With a difference as big as $10 \%$ in the two sub-samples. In terms of relative numbers, the difference amounts to half of the variance. In America, independent directors are mainly composed of chairmen from other companies or retired chairmen, university principals, retired government officials, private investors. This is because these people have substantial experience and can provide sincere, detailed and practical advices (Lou, 2001). There could be several possible explanations for the low percentage of independent industrialist directors in China: first, out of consideration of business secrets, Chinese listed companies are unwilling to appoint outside managerial personnel as their independent directors; second, as managers themselves, Chinese industrialists are too busy to hold concurrently posts of independent directors in other companies; ${ }^{7}$ Third, we are still not used to the idea of having outside managers from non-shareholding companies as our directors. There are, much to our delight, cases of listed companies have pointed managerial personnel from fund management companies as their independent directors, which we believe could be a starting signal of interlock director practice in China ${ }^{8}$.

2) The percentage of financial professionals on board is less than $10 \%$. Considering the Guidelines requires that there shall be at least one accounting professional on board, this proportion is far too low, implying many listed companies are unwilling to appoint accounting professionals as their independent directors. Without the mentioned government compulsory regulations, this situation could be even worse. One possible explanation could be that companies tend to regard their financial affairs as confidential. Therefore, they are unwilling to appoint outsiders as their independent financial directors. Even if they have to

\footnotetext{
5 "Economic management" refers to a wide variety of investment, financing, corporate management and economic theories. Ambiguities in the definition of this term may influence the research results. Comparatively speaking, Terms like accounting or law have clearer definitions and narrower ranges. If we define economic management more explicitly, some of the data we obtained on "economic management" may change accordingly.

${ }^{6}$ The results are not representative due to serious data missing problems.

${ }^{7}$ This can be explained by the differences between A share only companies and B (H) share companies.

${ }^{8}$ Those who were appointed as the first independent trustees of state-owned companies by Guangzhou government include board of directors, directing managers, renowned researchers and experts.
} 
so, they intend to delay as much as possible ${ }^{9}$ or take wait-and-see attitudes. Therefore, the Guidelines have played a positive role in optimizing the personnel structure of Chinese boards of directors.

3) Noticeably, over $20 \%$ current independent directors are more than 60 years old, and the oldest is $90^{10}$. As noted earlier, Kong (2001) asserted that the prime time for independent directors is from 35 to 55 . Directors younger than 35 are lack of necessary experience, whereas older than 55 may be in need of more energy and work motivation. In addition, as retirement approaches, one's social capital, knowledge, and business experiences start to diminish increasingly. Statistics show that people's social capital reduce by half in the first two years of retirement. More importantly, the allowance one gets as an independent director may become very important to a retiree that he can not afford to lose the job. Under such circumstances, his independence as an independent director may be affected. A British research specialized in independent director institution claimed that for the majority, the best time of being an independent directory is 10 years before the retirement and one can create maximum value for his company in this period because of the following reasons (1). People at this stage can reach the climax of their careers while still have enough energy and motivation; (2). They are worthy of being invested since they can still serve the companies for a long time; (3) Their social capital reaches the top point at this stage for most of their peers and friends are holding important posts; (4). They are regarded by others as promising, rather than as quasi-retirees. (Kong, 2001).

But the situation is different in China. Chinese people respect the elder. Senior age itself is a kind of "capital". This might be the reason that Chinese independent directors tend to be elderly. Of course, there are still other possibilities: some companies may hope those elder independent directors have no enough energy to interfere with the company's daily business operation. Also, by appointing prestigious elders their independent director, companies can enhance reputation of their own. Meanwhile, since most of these elder independent directors are social elites, have conformable income and deeply influenced by traditional culture, Chinese elder independent directors are unlikely to conspire with listed companies in order to keep their posts. However, lack of energy or health problem may seriously affect their independence. Therefore, it is necessary for us to gradually reduce the percentage of elderly independent directors in the future.

\footnotetext{
${ }^{9}$ Statistics shows (adopted from the $7^{\text {th }}$ issue of Chinese Enterpreneurs, 2001, p. 64), among total number of independent directors in 52 listed companies, 44 (11.9\%) are financial professionals. On one hand, the percentage is twice as high as the percentage of independent directors on board; on the other hand, the percentage is much lower than that of technology directors (39.4\%), implying a lot of companies still have the tendencies of emphasizing technology and ignoring management.

${ }^{10}$ For example, as an extreme case, Mingsheng Banking Corp., Ltd has three independent directors age 73,85 and 91 respectively.
} 


\subsection{Number of companies in which independent directors concurrently serve}

For independent directors, whether they concurrently holding positions in one or several listed companies could have significant influences on their performances. Needless to say, a person's energy and time is limited. And the expertise needed for decision making varies with different companies. When one independent director holds concurrently several posts at several different companies, He may run short of time, energy as well as expertise to carry out his duties satisfactorily. In America, it is common some directors hold concurrently independent director posts in several listed companies. People call them "super director" and watch them with growing distrust. In the recent scandals of Enron and WorldCom, most of the two companies' independent directors are these super directors and they failed to perform their duties as effective supervisors. The Guidelines (draft for comments) require each independent director shall work in the company for no less than 15 days per year. The Guidelines also promulgate that "In principle, independent directors can only hold concurrently the post of independent directors in five listed companies at maximum" to ensure "they shall have enough time and energy to perform the duties of the independent directors effectively."

Table 7 shows the number of companies in which Chinese independent directors concurrently serve. A majority of independent directors $(85.52 \%)$ serve only one listed company. $9.47 \%$ hold concurrently independent posts at two listed companies. Only a small fraction concurrently serves more than three companies, which, to a certain extent, provides guarantee for Chinese independent directors to perform their supervision duties.

Table 7 Number of companies in which independent directors concurrently serve

\begin{tabular}{lcc}
\hline Number of companies served & Number of independent director & Rate/\% \\
\hline 6 & 1 & 0.05 \\
5 & 11 & 0.50 \\
4 & 32 & 1.45 \\
3 & 65 & 2.95 \\
2 & 207 & 9.38 \\
1 & 1891 & 85.67 \\
Total & 2207 & 100.00 \\
\hline
\end{tabular}

\subsection{Geographic distribution of independent directors}

Fig. 1 depicts a combined geographic distribution of listed companies and their independent directors, the conclusions are drawn as follows:

1) $45 \%$ listed companies prefer to hire local people as independent directors. Possible reasons are: first, local people know the practical situation of the area better, which is beneficial to the company's decision making; second, it can be 


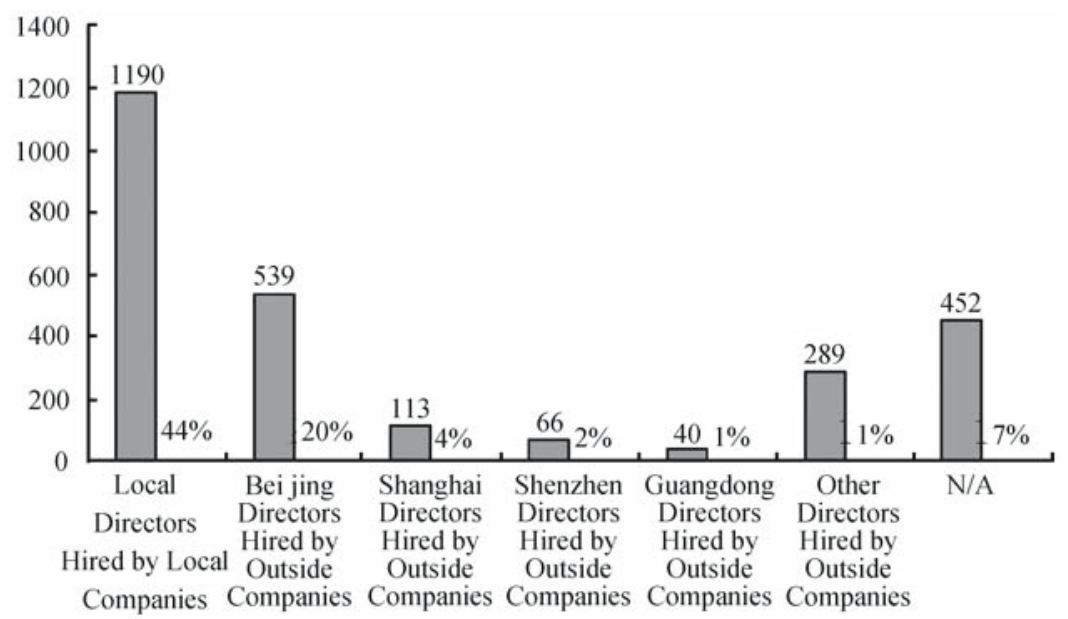

Fig. 1 Combined geographic distribution of listed companies and their independent directors

cost-effective; finally, recruiting local independent directors could reduce costs caused by various government supervision and regulation since local independent directors, as local elites, usually keep good relationship with local governments. Companies can thus suffer less government supervision.

2) Most independent directors are from politically or economically developed cities or regions. Table 8 shows that Beijing, Shanghai, Shenzhen, and Guangdong dominate the top 4 on the list. As depicted in Fig. 1, the number of Beijing independent directors hired by outside companies is 539 (20\%). As noted earlier, a majority of Chinese independent directors are teachers and researchers from prestigious universities or colleges. We also mentioned that listed companies tend to appoint social elites their independent directors. Since Beijing has

Table 8 Top 10 cities/provinces with largest number of independent directors

independent directors

\begin{tabular}{llr}
\hline 1 & Beijing & 638 \\
2 & Shanghai & 332 \\
3 & Shenzhen & 137 \\
4 & Guangdong & 105 \\
5 & Sichuan & 90 \\
6 & Jiangsu & 84 \\
7 & Shandong & 80 \\
8 & Zhejiang & 80 \\
9 & Fujian & 69 \\
10 & Liaoning & 66 \\
\hline
\end{tabular}


largest number of prestigious universities and social celebrities in China, it is understandable that largest number of independent directors is from the city. In addition, economically developed regions (such as Guangdong Province) have more listed companies and naturally more independent directors. As for Shanghai and Shenzhen, both of them have a stock market located in their cities, which naturally gives rise to more independent directors.

\section{Relationship between the percentage of independent directors on board and company performance}

\subsection{Number and percentage of independent directors on board}

As a precondition, independent directors have to make up the majority of the board to perform their duties effectively. Too few in number or too low a percentage will impair the independent directors' supervision capability. On the other hand, too many independent directors on board also exert negative impacts upon the board's decision-making efficiency due to the problem of information asymmetries and limitation of independent directors' expertise.

Chen and Jia (2002) adopted indices of corporate governance efficiency to appraise independent director's performance in a company. Corporate governance efficiency refers to the decision-making efficiency of the board of directors, including the principles of adaptability and fairness. The former indicates the operation ability of the board's decisions: whether the decisions made by the board are consistent with the company's practical situation and whether these decisions can be smoothly implemented and bring forth expected results; the latter refers to whether the board's decisions are shareholder-oriented, i.e. aiming at maximizing shareholders' interests and rights. Chen et al. argued that with the increase of independent directors on board, the board's supervision over management is enhanced, so does the principle of fairness. One the other hand, since independent directors are not involved in the company's daily operation, the problem of information asymmetries will deteriorate as the number of independent director increases, which in turn reduces the board's decision-making efficiency (adaptability). As marginal efficiency diminishes while marginal cost increases, changes in corporate governance efficiency follows a " $\cap$ " shape curve (as depicted in Fig. 2).

Taken together, the percentage of independent directors on a board is contingent on the company's practical situation. There are still other factors affecting the number of independent directors on board, such as compulsory government regulations, industry the company currently in, business environment, company growth, profitability, etc. Hermalin and Weisbach (1998) found that when a 


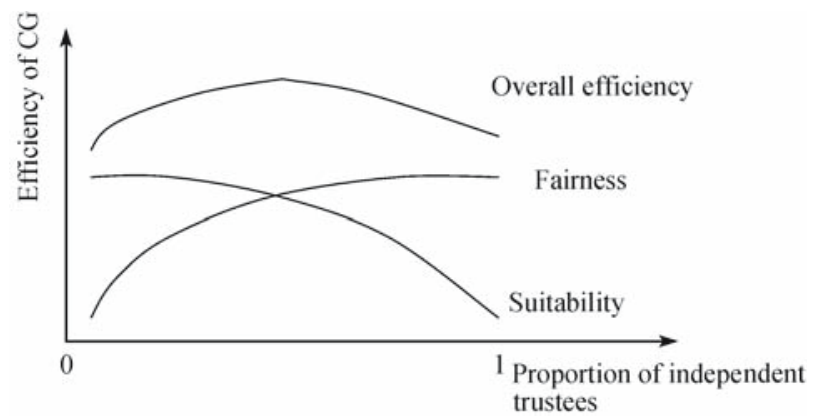

Fig. 2 Relationship between corporate governance efficiency and percentage of independent directors on board

company's performance declines, the percentage of independent directors on board will go up, indicating company performance influences the board composition. However, Denis and Sarin's research (1999) argued that independent's percentage on board remains more or less the same in the long run. They found that the number of independent directors in high-independentdirector-percentage companies gradually decrease over time and visa versa. Ronald (1998) suggested that companies carry out business in a wide range of fields tend to have a high percentage of independent directors; whereas companies under government supervision usually co-opt independent directors with government working background or law professionals. In contrast, Kole and Lehn (1999) found, based on their study on air companies after the release of government supervision on the aviation industry, that changes in corporate governance mechanism does not significantly affect the percentage of independent directors on board. Hersbach (1988) and Denis and Sarin (1999) found that if a company's founder has great influence in the company or a CEO holds a large share of his company stocks, the company is likely to form "insider" boards; whereas companies with long history or with professional managers tend to form "outsider" boards. They also showed companies facing financial distresses or dividend cuts usual have less number of independent directors since few are willing to work in a "problem" company. Hermalin and Weisbach (1988) found that when retirement approaches, a CEO is inclined to appoint more endogenouslychosen directors, whereas at times of financial crisis, he is prone to appoint more outside directors. Kaplan and Minton (1994) confirmed that companies in Japan followed the same rules (Lou, 2001; Lou and Yuan, 2002).

In U.S.A, the percentage of independent directors on board rose steadily during 1970s and 1980s. Statistics show that, on average, about 60\% American directors are from the outside. So far, however, no existing literature has demonstrated that what the optimal percentage is for independent directors on board so that the board can perform it duties to a maximum. 
Tables 9, 10 and 11 illustrate respectively the dissertation of board size, the number percentage of independent directors on board.

Table 9 Distribution of board size of chinese listed companies

\begin{tabular}{lcrrrrr}
\hline Board size & \multicolumn{7}{c}{ Number of Listed Companies } \\
\cline { 2 - 7 } & A share only & Percent & B(H) share & Percent & Total & Percent \\
\hline 5 & 7 & 0.67 & & & 7 & 0.59 \\
6 & 5 & 0.48 & & & 5 & 0.42 \\
7 & 108 & 10.32 & 17 & 12.23 & 125 & 10.54 \\
8 & 69 & 6.59 & 8 & 5.76 & 77 & 6.49 \\
9 & 371 & 35.44 & 37 & 26.62 & 408 & 34.4 \\
10 & 54 & 5.16 & 7 & 5.04 & 61 & 5.14 \\
11 & 234 & 22.35 & 36 & 25.90 & 270 & 22.77 \\
$12-20$ & 199 & 18.99 & 34 & 24.45 & 233 & 19.65 \\
Total & 1047 & 100.00 & 139 & 100.00 & 1186 & 100.00 \\
\hline
\end{tabular}

Table 10 Distribution of the number of independent directors on board

\begin{tabular}{lrrrrrr}
\hline $\begin{array}{l}\text { Number of } \\
\text { independent } \\
\text { directors }\end{array}$ & A share Only & Percent & B(H) share & Percent & Total number & Percent \\
\cline { 2 - 7 } & 25 & 2.39 & 6 & 4.32 & 31 & 2.61 \\
1 & 780 & 74.5 & 87 & 62.59 & 867 & 73.1 \\
2 & 202 & 19.29 & 31 & 22.30 & 233 & 19.65 \\
3 & 34 & 3.25 & 11 & 7.91 & 45 & 3.79 \\
4 & 4 & 0.38 & 4 & 2.88 & 8 & 0.67 \\
5 & 1 & 0.10 & & & 1 & 0.08 \\
6 & 1 & 0.10 & & & 1 & 0.08 \\
9 & 1047 & 100.00 & 139 & 100.00 & 1186 & 100.00 \\
Total & & & & & &
\end{tabular}

Table 11 Distribution of the percentage of independent directors on board

\begin{tabular}{lcccrrr}
\hline $\begin{array}{l}\text { Percentage of } \\
\text { independent } \\
\text { directors }\end{array}$ & A share only & Percent & B(H) share & Percent & Total & Percent \\
\cline { 2 - 7 } $0-10$ & 19 & 1.18 & 3 & 2.16 & 22 & 1.85 \\
$11-20$ & 361 & 34.48 & 46 & 33.09 & 407 & 34.32 \\
$21-30$ & 533 & 54.91 & 63 & 45.32 & 596 & 50.25 \\
$31-40$ & 119 & 11.37 & 25 & 17.99 & 144 & 12.14 \\
$41-50$ & 13 & 1.24 & 2 & 1.44 & 15 & 1.26 \\
over 51 & 2 & 0.19 & 0 & 0 & 2 & 0.17 \\
Total & 1047 & 100 & 139 & 100 & 1186 & 100 \\
\hline
\end{tabular}


Statistically, a board of directors in Chinese listed companies has 10.13 directors on average, including $2.28(22.5 \%)$ independent directors and 7.86 (77.5\%) non-independent ones. A majority of boards of directors are composed of nine $(33.22 \%)$ or eleven $(22.77 \%)$ directors ${ }^{11}$. Most companies $(71.75 \%)$ have two independent directors. Together with companies with three, over $90 \%$ Chinese listed companies have two or three independent directors. As for the percentage of independent directors on board, most companies (74.24\%) fall into the range of $11 \%-30 \%$. Only $13 \%$ A-share-only companies and $20 \% \mathrm{~B}(\mathrm{H})$ share companies have more than $30 \%$. Also, there is a small fraction of companies have only one independent director on board - there is still a long way to go to achieve the goals set by the CSRC. As shown in Table 9, for all items tested, no significant variance exists among all three sub samples, except that the number of $\mathrm{B}(\mathrm{H})$ share companies with $30 \%-40 \%$ independent directors is higher than that of A-share-only companies by $7 \%$, indicating the former is well ahead of the latter in meeting the requirement of the Guidelines.

\subsection{The percentage of independent directors on board and company performance}

The relationship between the independent director institution (usually embodied as the percentage of independent directors on board) and company performance is a seemingly easy, yet complicated question. The purpose of independent director institution is to weaken insider control, reduce agency cost, and raise the company's value. Yet researches have not reached an agreement on the real effects of the institution. Some found the number of independent directors on board is in direct proportion to company performance; others reached totally opposite conclusions; still others suggested there is no relationship between the above two. (Lou, 2001; Lou and Yuan, 2002; Gao and Ma, 2002). Wu et al. (2001) found a positive correlation between the percentage of none-executive directors ${ }^{12}$ and company performance. Gao and Ma (2002) suggested that Chinese listed companies performances are related to the independent director institution only in a very insignificantly positive way. In addition, $\mathrm{Hu}$ and Shen (2002) confirmed the relation between the said two is insignificant. In other words, listed companies' performance is immune to the percentage of independent directors to a large extent.

Below, we present a preliminary analysis of the relationship among company performance (company performance are assessed by means of calculating Return

\footnotetext{
${ }^{11}$ Boards tend to have an odd-number of directors for the convenience of voting. Even-numbered boards of directors are comparatively fewer.

${ }^{12}$ Here "none-executive" refers to those directors who do not hold any executive posts in a company. They are a bit different from the "independent directors" our article focuses on.
} 
on Net Asset (RONA) and Return on Total Asset (ROA) ${ }^{13}$, data obtained from listed companies annual reports in 2001 and 2002, percentage of independent directors on board, and their remuneration.

Tables 12 and 13 illustrate the relationship between company performance and the number and percentage of independent directors on board. After omitting some extreme values, we find that, starting with two independent directors, company performance improves as the number of independent director increases. Company performance reaches its climax with five independent directors. It then begins to decrease with the increase of independent directors in number. As the tables shown, companies with nine independent directors on board tend to perform worst. Taken together, companies perform better with $30 \%-40 \%$ independent directors on board and perform poorer with 20\%-30\%.

Considering the Guidelines were issued in Aug, 2001 and the relatively short history of Chinese independent director institution, independent director's contributions to his company may have not emerged yet. Therefore, we only focus on the relationship between the percentage of independent directors on board and company performance. As mentioned earlier, the establishment of independent director institution is mainly driven by government. Many listed companies appoint independent directors only catering to government requirement. Under such circumstances, out of consideration for expenses ${ }^{14}$, listed companies will choose to hire only least possible number of independent directors. Our results confirm that most of average-performance listed companies have only two independent directors on board, whereas high-performance companies tend to hire more independent directors so as to differentiate themselves from average-performance companies ${ }^{15}$ and send positive signals to potential investors and government regulatory departments, resulting in a state of "separated equilibrium" in the end. Besides, high-performance companies are able to afford more independent directors. This explains why there is a rough positive relationship between the number of independent directors and company

\footnotetext{
${ }^{13}$ How to measure company performance is highly debatable, and generally people use RONA to appraise it. Though RONA is widely criticized as being vulnerable to management manipulation, scholars have not found better replacement so far. Another commonly used measure, ROA, is not comparable among different companies since it is influenced by idiosyncratic company's profit and total equity value. Thus we can not use it to measure company performance in general. However, compare with RONA, ROA is less vulnerable to management manipulation. Thus we used both of the above two measures in our study. In addition, considering independent director institution was not fully implemented until August, 2001 (see the Guidelines), we only selected data from Dec. 31, 2001 to Jun. 30, 2002 in our study.

${ }^{14}$ Listed companies in China are influenced more by government regulatory bodies (such as CSRC) than from private investors; therefore, they are eager to reduce the government supervision imposed upon them to reduce the supervision cost.

${ }^{15}$ It is, of course, the minimum requirement set by the Guidelines.
} 


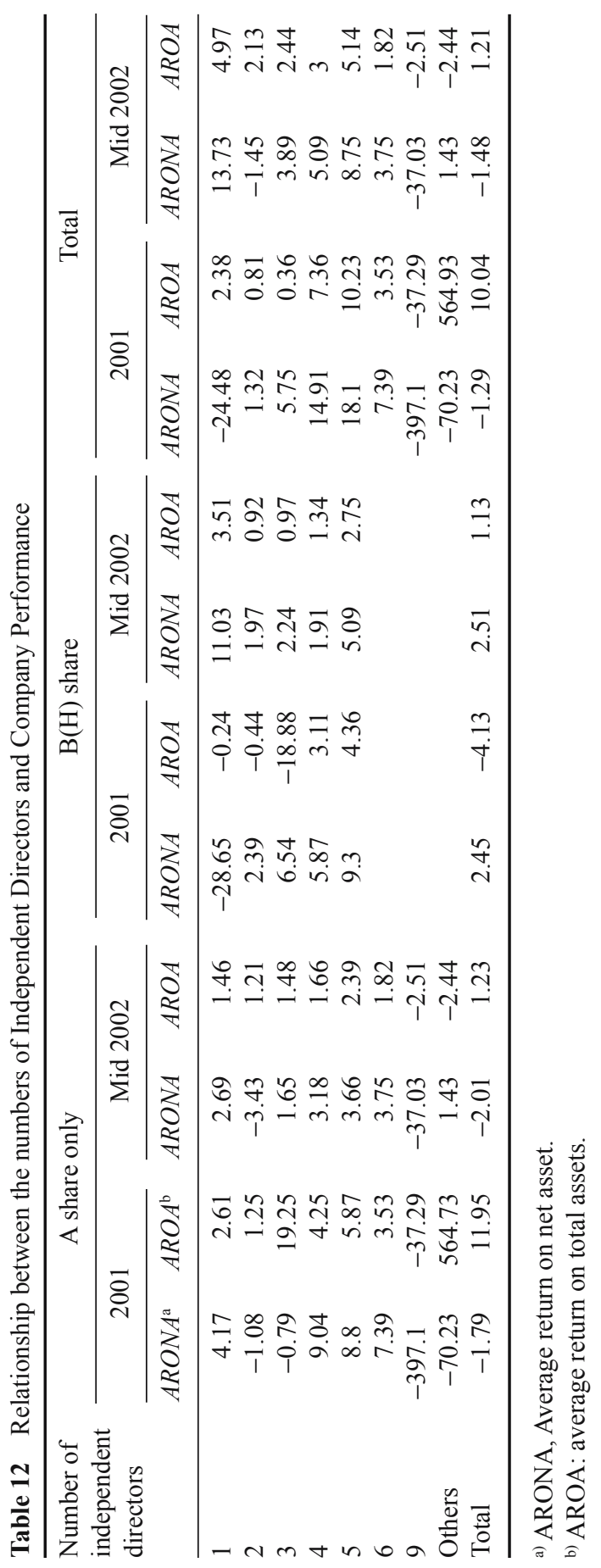




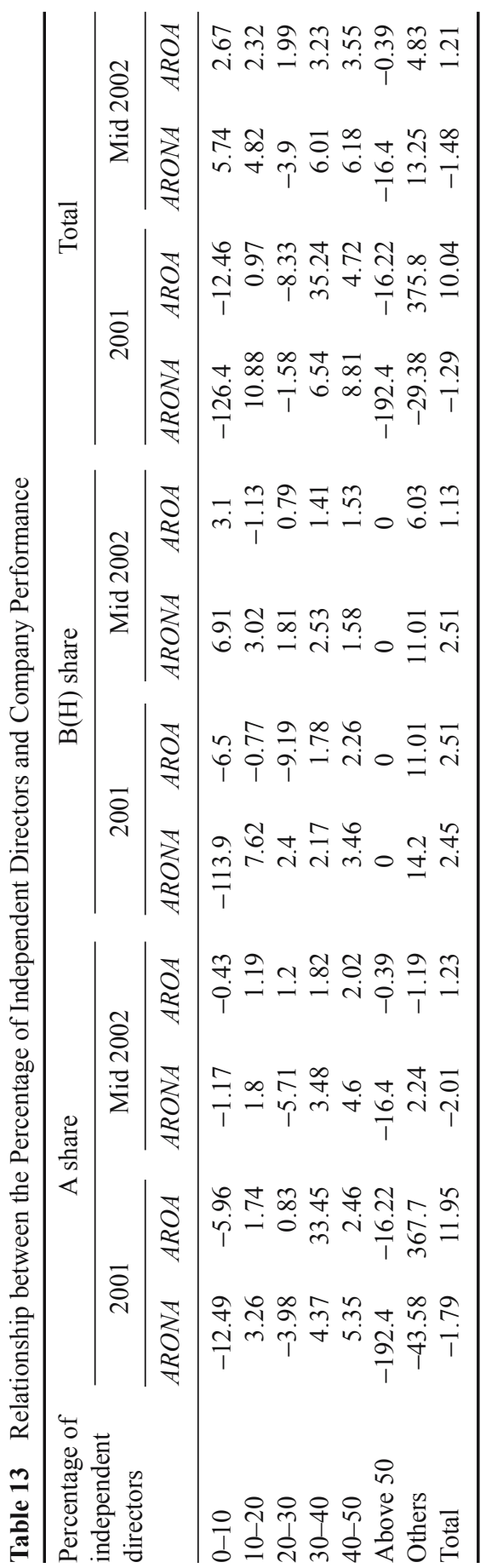


performance in China, whereas there is no significant relationship between the percentage of independent directors and company performance ${ }^{16}$. The Guidelines require that "by June 30, 2002, at least two members of the board of directors shall be independent directors; and by June 30, 2003, at least one third of board shall be independent directors." Since our data are collected from the interval between the above two dates, a lot of listed companies may have not yet completed their independent director appointment, leading to an insignificant relationship between the percentage of independent directors and company performance.

\section{Remuneration for independent directors and company performance}

\subsection{Analysis of remuneration for independent directors}

Remuneration for independent directors always gives rise to much controversy. The paradox is obvious: too poorly paid, independent directors will not be properly motivated and appear to be risk-averse, whereas too princely paid, independent directors will lose their independence owing to the fear of losing their jobs. Therefore, in order to ensure that independent directors perform their duties properly, strict regulations imposing controls over them are needed. Generally speaking, there are three commonly used incentives and control methods: (1) law and regulation (2) reputation mechanisms and (3) monetary incentives. Among them, the method of law and regulation emphasizes control over them, monetary incentives highlight motivation, and reputation mechanism stresses both control and motivation.

Independence is vital to the job of independent director. To keep independent, independent directors should not steer clear of having any substantial economic bonding with the company he serves, nor should he become too dependent on the remuneration he receives from the company. Motivations for independent directors are two-folded: first, monetary incentives; two, other types of incentives, such as a reputation mechanism.

Since independent directors' salary should not be too high and they need to keep their independence, a reputation mechanism is generally regarded as an effective way of both motivating and restraining independent directors. Scholars tend to believe that an independent director's success in his position will greatly boost his own reputation and human capital. Thus for the sake of their own prestige and fame, independent directors would endeavor to perform their duties, rather than conspire with management in case of financial fraud. By holding the post of independent director, an independent director sends out positive signals

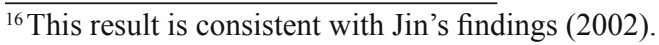


of his value to the outer world. Specifically, a famous independent director would work hard to maintain his reputation as an effective company supervisor. This explains why listed companies are fond of appointing prestigious scholars or social celebrities their independent directors, However, the question is, why should a rich and renowned social elite runs the risk of loosing his reputation by taking posts of independent director? What will he get in return? In consistency with the hypothesis of rational man, we suppose a reputation mechanism works only to those not-so-famous ones, or people want to be even more famous. This gives rise to another question: to a potential independent director, a motive for more fame is the same as a motive for money, both is likely to influence his independence if they become too dependent upon what the job brings him. Thus we argue that there is no real differences between reputation incentive and monetary incentive - they are all benefits that one can get from holding the post of independent director as well as the driving forces behind taking the post and hardworking. Whichever incentive we adopt, we should use it to a proper "degree".

Traditionally, remuneration for independent directors is based on a fixed allowance system, including annual payment, conference allowance, and perhaps allowance one gets from committees. An independent director's remuneration usually has nothing to do with the company's market performance. In a sense, this is reasonable since an independent director's job is to provide suggestions, regardless of the company performance. His workload is only related to the number of meetings he attends and his position in the board of director, but not to the company's performance. What's more, when a company is facing financial distress, its independent directors probably need to work even harder- the more problems the company has, the more suggestions the company needs, the heavier and the independent directors' workload. Another disadvantage of connecting independent directors' remuneration with the company's performance is that independent directors may get too involved into the company's operation and business to maintain their independence.

Nevertheless, an increasing number of scholars start to realize that, unless properly motivated, independent directors would not endeavor to perform their duties and an independent director's job is actually closely related to the company's performance. These scholars thus suggest that listed companies should keep their independent directors' interests consistent with the shareholders' and motivate their independent directors by means of increasing their remuneration, connecting their remuneration with company performance, and offering higher basic salaries and stock options. ${ }^{17}$ Pound (1995) pointed out that there should be a

\footnotetext{
${ }^{17}$ China Securities Journal (Jan. 8, 2003) reported as required by government, large companies in U.K. have raised salary of non-executive directors drastically. Among them, EMI has announced it is going to raise the basic salary of its non-executive directors from 37,000 pounds a year 50,000. EMI's non-executive directors work about 30 days annually.
} 
link between board members' income and the service they offered. Otherwise, companies can not expect them to work hard and take responsibilities. He suggested independent directors' payment (currently $\$ 25,000$ in median-sized companies and $\$ 50,000$ in big companies) should increase five times plus stock option offerings. Morck et al. (1998) found, by using Tobin's Q measurement, a positive relation between company performance and amount of stock option held by board members. Hermalin and Weisbach (1998) confirmed that a motivation-based reward system can enhance independent directors' supervision efficiency (Lou, 2001).

Recently, "more and more companies (outside China), in addition to traditional monetary allowance, have started to pay their independent directors in forms restricted shares or stock option. Some go even further to pay exclusively restricted shares or stock option" (Walter, 1993). Statistics of The Investor Responsibility Research Center (IRRC) shows that the number of companies offering stock option to their independent directors has increased steadily. By 1997, over half of Standard \& Poor's 500 companies have adopted the stock option incentive.

The Guidelines requires that "listed companies shall grant the appropriate allowance to the independent director. The standard of the allowance shall be proposed by the board of directors' meeting, approved by the shareholders' meeting, and be disclosed in the company's annual report. The independent director shall not receive any extra non-disclosed interests and compensation from the listed company, its major shareholders, or other interested entities and individuals other than the above-mentioned allowance." We should notice that the Guidelines neither regulate how should independent director's allowance be granted, nor set a standard for maximum remuneration. It simply says listed companies "shall grant the appropriate allowance to the independent director". In our opinion, "appropriate" means an allowance can motivate independent directors while still keeping their independence.

As for the disclosure of independent directors' allowance, the Guidelines require that the allowance shall be disclosed in a company's annual report. However, we think a disclosure of the independent directors' annual allowance is not enough. As noted earlier, the foundation of independent director institution is independence itself. Independent directors' remuneration shall not be too high to influence his independence. More specifically, an independent director's remuneration shall not be so high that he becomes dependent upon it. So the point is not how much money an independent director receives from the company he works for, but the percentage of his annual income as an independent director to his total annual income, in other words, his degree of reliance upon his independent director remuneration. To illustrate, an annual allowance of 50,000 could means so much to an independent director with an annual income of merely 
100,000 that his independence may be affected. ${ }^{18}$ Likewise, how much money one currently has will affect his attitude toward the independent director's remuneration. As a corollary, we believe a disclosure of both an independent director's annual allowance and the amount of his personal wealth is necessary for us to judge his independence in a company. ${ }^{19}$

As a rule, Chinese listed companies usually pay their independent directors by fixed annual allowance. Table 14, 15, and 16 present the distribution of independent directors' annual allowance in different types of listed companies and in different regions. ${ }^{20}$

Table 14 Distribution of the Annual Allowance of Independent Directors

\begin{tabular}{|c|c|c|c|c|c|c|c|c|}
\hline \multicolumn{3}{|c|}{$\begin{array}{l}\text { A Share only sample } \\
\quad(10,000 \text { yuan })\end{array}$} & \multicolumn{3}{|c|}{$\begin{array}{l}\text { ABH Share sample } \\
(10000 \text { yuan })\end{array}$} & \multicolumn{3}{|c|}{$\begin{array}{l}\text { Total samples } \\
(10000 \text { yuan })\end{array}$} \\
\hline $\begin{array}{l}\text { Annual } \\
\text { allowance }\end{array}$ & $\begin{array}{l}\text { Number } \\
\text { of people }\end{array}$ & Percent & $\begin{array}{l}\text { Annual } \\
\text { allowance }\end{array}$ & $\begin{array}{l}\text { Number } \\
\text { of people }\end{array}$ & Percent & $\begin{array}{l}\text { Annual } \\
\text { allowance }\end{array}$ & $\begin{array}{l}\text { Number } \\
\text { of people }\end{array}$ & Percent \\
\hline under 2 & 232 & 9.86 & under 2 & 33 & 9.79 & under 2 & 265 & 9.85 \\
\hline $2-4$ & 919 & 39.07 & $2-4$ & 105 & 31.16 & $2-4$ & 1024 & 38.08 \\
\hline $4-6$ & 302 & 12.84 & $4-6$ & 34 & 10.09 & 4-6 & 336 & 12.50 \\
\hline $6-8$ & 61 & 2.59 & $6-8$ & 16 & 4.75 & $6-8$ & 77 & 2.86 \\
\hline $8-10$ & 22 & 0.94 & $8-10$ & 7 & 2.08 & $8-10$ & 29 & 1.08 \\
\hline Above10 & 8 & 0.34 & Above 10 & 2 & 0.59 & Above 10 & 10 & 0.37 \\
\hline N/A & 808 & 34.36 & N/A & 140 & 41.54 & N/A & 948 & 35.26 \\
\hline Total & 2352 & 100.00 & Total & 337 & 100.00 & Total & 2689 & 100.00 \\
\hline
\end{tabular}

As shown in Table 14, the average annual allowance for Chinese independent directors is 33412.16 yuan. A majority of them receive 20,000-40,000 yuan a year. Another considerable fraction receives less than 20,000 yuan or more than 40,000 yuan (but less than 60,000). As mentioned earlier, most of the Chinese independent directors are renowned university teachers, prestigious experts, or senior managers with comfortable incomes. Therefore, an annual allowance of about 30,000 yuan is not likely to be detrimental to their independence. ${ }^{21}$ Table 15

\footnotetext{
${ }^{18}$ Here we hypothesize that people are similar in every aspect, e.g. their needs and their desires for economic interest, etc.

${ }^{19}$ The question is, is it fair to the independent directors to disclose their personal wealth to the public? If you regard independent directors as public figures, the answer becomes obvious. But whether independent directors are public figures depends on how the independent director institution defines them. In China, independent directors are generally regarded as "quasi-public figures" or "grey public figures".

${ }^{20}$ Though Shenzhen is part of Guangdong province, we measured it separately due to its large number of listed companies.

${ }^{21}$ Many take post of independent directors for other reasons rather than economic rewards, e.g. Guanxi, out of academic research reasons, higher reputation or expansion of their social network in the business world.
} 
Table 15 Geographic distribution of the annual allowance of independent directors

\begin{tabular}{|c|c|c|c|c|c|c|c|c|c|}
\hline \multirow[t]{2}{*}{ Province } & \multicolumn{2}{|c|}{$(0,2)$} & \multicolumn{2}{|c|}{$(2,4)$} & \multicolumn{2}{|c|}{$(6,8)$} & \multicolumn{2}{|c|}{$(8,10)$} & \multirow[b]{2}{*}{ Rank } \\
\hline & Percent & Rank & Percent & Rank & Rank & Percent & Rank & Percent & \\
\hline Anhui & 13.5 & 18 & 81.08 & 2 & 25 & 0 & 16 & 0 & 10 \\
\hline Beijing & 2.3 & 29 & 55.17 & 24 & 4 & 6.9 & 11 & 2.3 & 8 \\
\hline Chongqing & 27.9 & 9 & 30.23 & 30 & 5 & 11.63 & 5 & 0 & 10 \\
\hline Hubei & 30.49 & 7 & 65.85 & 11 & 28 & 0 & 16 & 0 & 10 \\
\hline Fujian & 4.08 & 27 & 59.18 & 18 & 6 & 8.16 & 9 & 0 & 10 \\
\hline Guangdong & 5.38 & 25 & 62.37 & 12 & 12 & 8.6 & 7 & 3.23 & 7 \\
\hline Gansu & 61.9 & 2 & 23.81 & 32 & 29 & 14.29 & 3 & 0 & 10 \\
\hline Guangxi & 12 & 19 & 48 & 26 & 13 & 20 & 1 & 0 & 10 \\
\hline Guizhou & 0 & 4 & 85 & 1 & 17 & 0 & 16 & 0 & 10 \\
\hline Heilongjiang & 34.62 & 14 & 57.69 & 21 & 23 & 0 & 16 & 0 & 10 \\
\hline Hebei & 16.67 & 13 & 60.42 & 13 & 14 & 0 & 16 & 4.17 & 10 \\
\hline Henan & 6.9 & 8 & 79.31 & 3 & 18 & 0 & 16 & 0 & 4 \\
\hline Jilin & 29.7 & 21 & 58.33 & 20 & 27 & 8.33 & 8 & 0 & 10 \\
\hline Jiangsu & 11.65 & 12 & 68.93 & 8 & 19 & 1.94 & 15 & 4.85 & 3 \\
\hline Jiangxi & 25 & 5 & 75 & 5 & 30 & 0 & 16 & 0 & 10 \\
\hline Liaoning & 31.17 & 22 & 59.74 & 16 & 22 & 0 & 16 & 0 & 10 \\
\hline Inner Mongolia & 11.11 & 12 & 66.67 & 10 & 21 & 11.11 & 6 & 0 & 10 \\
\hline Ningxia & 43.75 & 3 & 56.25 & 22 & 31 & 0 & 16 & 0 & 10 \\
\hline Hainan & 0 & 29 & 78.95 & 4 & 11 & 0 & 16 & 0 & 10 \\
\hline Qinghai & 75 & 1 & 25 & 31 & 32 & 0 & 16 & 0 & 10 \\
\hline Shaanxi & 25.58 & 11 & 69.77 & 7 & 26 & 0 & 16 & 0 & 10 \\
\hline Sichuan & 11.88 & 20 & 60.4 & 14 & 7 & 0 & 16 & 0 & 10 \\
\hline Shandong & 25.77 & 10 & 59.79 & 15 & 20 & 3.09 & 14 & 0 & 10 \\
\hline Shanghai & 4.18 & 26 & 55.65 & 23 & 3 & 3.35 & 13 & 0.84 & 9 \\
\hline Shanxi & 16 & 16 & 68 & 9 & 16 & 0 & 16 & 0 & 10 \\
\hline Shenzhen & 15.15 & 17 & 36.36 & 28 & 15 & 17.17 & 2 & 7.07 & 2 \\
\hline Tianjin & 18.92 & 13 & 59.46 & 17 & 9 & 0 & 16 & 0 & 10 \\
\hline Hunan & 5.66 & 24 & 58.49 & 19 & 8 & 7.55 & 10 & 3.77 & 6 \\
\hline Xinjiang & 0 & 29 & 42.42 & 27 & 2 & 12.12 & 4 & 9.09 & 1 \\
\hline Tibet & 16.67 & 15 & 33.33 & 29 & 1 & 0 & 16 & 0 & 10 \\
\hline Yunnan & 31.03 & 6 & 55.17 & 25 & 24 & 6.9 & 12 & 0 & 10 \\
\hline Zhejiang & 2.53 & 28 & 72.15 & 6 & 10 & 0 & 16 & 3.8 & 5 \\
\hline
\end{tabular}

Table 16 Total distribution of the annual allowance of independent directors

\begin{tabular}{lc}
\hline Annual allowance (10000 yuan) & Percent \\
\hline Under 2 & 15.22 \\
$2-4$ & 58.82 \\
$4-6$ & 19.3 \\
$6-8$ & 4.22 \\
$8-10$ & 1.67 \\
Above 10 & 0.57 \\
Total & 100 \\
\hline
\end{tabular}




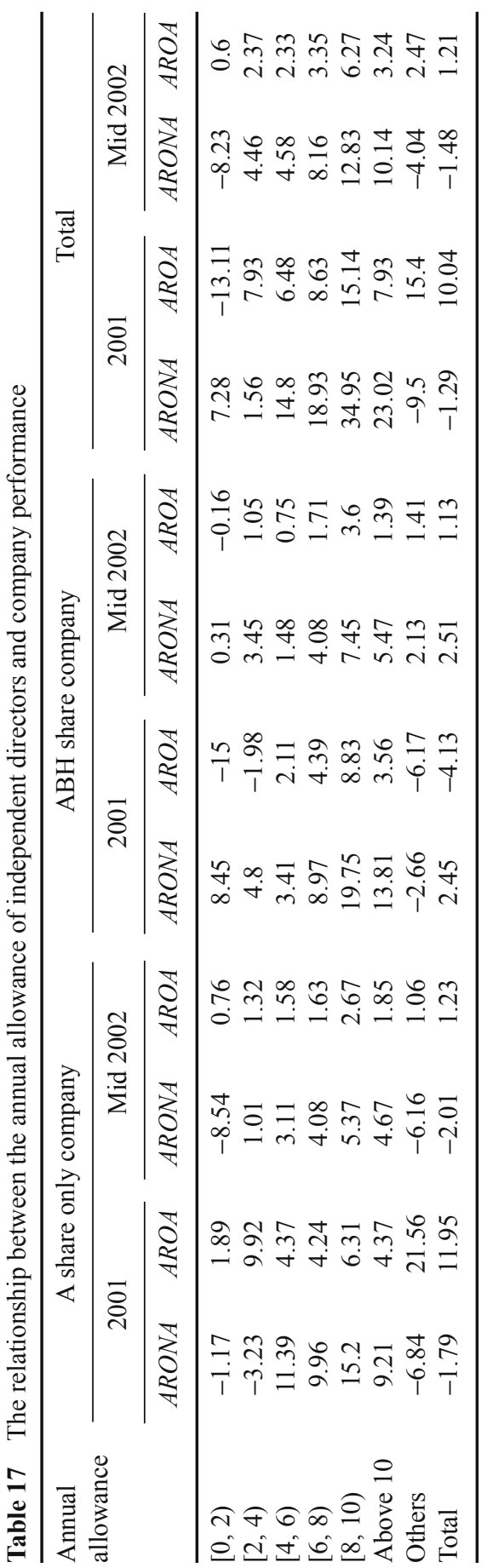


shows the geographic distribution of independent directors' allowance, exhibiting little variance among different regions. But independent directors with an annual allowance higher than 80,000 yuan mostly locate in economically developed cities or provinces such as Beijing, Guangdong, Jiangsu, Shanghai, Shenzhen, Zhejiang, etc., indicating a certain relationship between independent directors' annual allowance and local economic development level.

\subsection{Independent directors' remuneration and company performance}

We already discussed that the remuneration designed for independent directors should take into consideration of both their independence and job motivation. In China, the prevailing remuneration system for independent directors is still a fixed allowance one, regardless of the company performance. As noted, a fixed remuneration system is harmless to independent director's independence, but it may be detrimental to independent director's work motive. Table 17 exhibits the relationship between independent directors' annual allowance and company performance. Starting with the interval of 20,000-40,000 yuan, there is a significant positive relation between the annual allowance and company performance. The latter reaches its climax at the interval of 80,000-100,000 yuan. Annual allowance over 100,000 negatively affects company's performance. Considering the short history of independent director institution in China, some of the independent directors' contributions to his company may have not yet emerged. Moreover, the higher annual allowance for independent directors, the higher a company's expenses. High-performance companies can afford higher number of independent directors and they tend to offer higher annual allowance as well. From a signal transferring point of view, since the disclosure of independent directors' annual allowance is a must, a higher independent director's annual allowance would send favorable signals to outsiders. Potential investors and government department concerned are thus able to sort out high-performance companies from poor-performance ones.

\section{References}

Brickley J, Coles J, Terry R (1994). Outside directors and the adoption of poison pills. Journal of Financial Economics, (35): 371-390

Chen Honghui, Jia Shenghua (2002). Improvement on Information Resourcing, Efficiency Substitution, and Role of Board of Directors. China Industrial Economy, (2): 79-85 (in Chinese)

Christor J, Burk, Kennis A (2000). Directors of board affairs in 1997: The practice of 1500 standard pull super-large firms. In: Liang Neng, et al. Corporate Management StructureComparative Experience in China and America. Beijing: Renmin University of China Press, 262-312 
Denis D J, Sarin A (1999). Ownership and board structures in publicly traded corporations. Journal of Financial Economics, (52): 187-224

Gao Minghua, Ma Shouli (2002). Analysis on independent director system and corporate performance. Nankai Economics Journal, (2): 64-68 (in Chinese)

Hermalin, Benjamin E, Weisbach, Michael S (1988). The determinants of board composition. Rand Journal of Economics, (18): 589-606

Hermalin, Benjamin E, Weisbach, Michael S (1998). Endogenously chosen boards of directors and their monitoring of the CEO. American Economic Review, (88): 96-118

$\mathrm{Hu}$ Qinqin, Shen Yifeng (2002). Issues on whether independent directors better corporate performance. Economic World, (7): 55-62 (in Chinese)

Jin Yonghong (2002). Independent directors: only when they are independent enough. Listed Companies, (11): 34-38 (in Chinese)

Kaplan, Steven N, Minton, Bernadette A (1994). Appointments of outsiders to Japanese boards: Determinants and implications for managers. Journal of Financial Economics, (36): 225257

Kong Xiang (2001). Research on independent directors. Report on Shenzhen Stock Exchange Center, (30): 21-28 (in Chinese)

Kong Xiang (2002). Comparison on domestic and abroad independent director system. Management World, (8): 88-96 (in Chinese)

Li Yougen, Zhao Xiping, Li Huaizu (2001). Research on structure of board of directors of listed companies and corporate performance. Chinese Industrial Economy, (5): 48-53 (in Chinese)

Lou Fang (2001). Recent research on abroad independent director system. Abroad Economies and Management, (12): 24-29 (in Chinese)

Lou Fang, Yuan Qihong (2002). Independent director system: issues in western and Chinese practices. Revolution, (2): 51-57 (in Chinese)

Morck R, Shleifer A, Vishny R (1988). Management ownership and market valuation: an empirical analysis. Journal of Financial Economics, (36): 225-257

Pound J (1995). The prospect of corporate management. In: Walter S J, et al. Corporate Management-Harvard Business Review (in Chinese, translated by Sun Jingwei and Gao Xiaohui). Beijing: Renmin University of China Press, 73-93

Rosenstein S, Wyatt J G (1990). Outside directors, board independence, and shareholder wealth. Journal of Financial Economics, (26): 175-192

Shen Yifeng (2001). Academic opinions on independent director system. Certified Public Accountant, (10): 26-29 (in Chinese)

Shi Xinghui (2001). Who are they? Analysis on 104 independent directors. China Entrepreneur, (7): 17-23 (in Chinese)

Walter S J (2001). Harvard Review on Corporate Governance

Wei Ai (2002). Current issues on independent director system of listed companies. Listed Companies, (11): 11-17 (in Chinese)

Wu Shukun, Liu Zhongming, Fan Jianqiang (2001). Diagnosis research on none-executive independent directors and company performance. Chinese Industrial Economy, (9): 80-87 (in Chinese) 